\title{
Study on Hiring Process of Wipro Infrastructure Engineering at Hindupur, India
}

\author{
Dr. Nalla Bala Kalyan, Dr. J. Viswanath \\ Associate Professor, Department of Management Studies, \\ S V College of Engineering, Karakambadi Road, Tirupati, India
}

\begin{abstract}
Human Resource Management (HRM) is an approach to the manage people, based on four fundamental principles, recruitment, selection, training, compensation, first human resources are the most important asset of an organization and their effective management is the key to its success. Specifically, the activities included are - HR planning, job analysis and design, recruitment and selection, orientation and placement, training and development, performance appraisal and job evaluation, employee and executive remuneration, motivation and communication, welfare, safety and health, industrial relations and the like. In this study helps the organization to identify the vicinity of problem and suggest way to progress the recruitment and selection process, this study center of attention on understanding recruitment and selection process. The research was done using both primary and secondary data.
\end{abstract}

Keywords: Human Resource, Management, Organization, Recruitment, Selection

\section{INTRODUCTION}

"Human Resource Management is the planning, organizing directing and controlling of the procurement, development, compensation, integration, maintenance and separation of human resources to the end that individual, organizational and social objectives are accomplished". Recruitment is a 'linking function' joining together those with jobs to fill and those seeking jobs. Recruiting makes it possible to acquire the number and types of people necessary to ensure the continued operation of the organization. Recruiting is the discovering of potential applicants for actual or anticipated organizational vacancies. "Selection is the process in which candidates for employment are divided into two classes those who are to be offered employment and those who are not. Selection means a process by which qualified personnel may be chosen from the applicants offering their services to the organization for employment".

\subsection{Recruitment Process}

Recruitment refers to the process of identifying and attracting job seekers so as to build a pool of qualified job applicants. The process comprises five interrelated stages, viz.

A. Job analysis

B. Sourcing

C. Screening and selection

D. On boarding

A. Job analysis:

The proper start to a recruitment effort is to perform a job analysis, to document the actual or intended requirement of the job to be performed. This information is captured in a job description and provides the recruitment effort with the boundaries and objectives of the search. Oftentimes a company will have job descriptions that represent a historical collection of tasks performed in the past. These job descriptions need to be reviewed or updated prior to a recruitment effort to reflect present day requirements. Starting recruitment with an accurate job analysis and job description ensure the recruitment effort starts off on a proper track for success.

\section{B. Sourcing:}

Advertising, a common part of the recruiting process, often encompassing multiple media, such as the internet, general newspapers, job and newspapers, professional publications, window advertisements, job centers, and campus graduate recruitment programs; and Recruiting research, which is the proactive 
identification of relevant talent who may not respond to job postings and other recruitment advertising methods done in first method. This initial research for so-called passive prospects, also called name generation, results in a list of prospects who can then be contacted to solicit interest obtain a resume/CV, and be screened.

\section{Screening and selection:}

Suitability for a job typically assessed by looking for skills, e.g. Communication, typing, and computer skills, Qualifications may be shown through resumes, job applications, interviews, educational or professional experience, the testimony of references, or in-house testing, such as for software knowledge, typing skills numeracy, and literacy, through psychological tests or employment testing. Other resume screening criteria may include length of service, job titles and length of time at job. In some countries, employers are legally mandated to provide equal opportunity in hiring. Business management software is used many recruitment agencies to automate the testing process. Many recruiters and agencies are using an applicant tracking system to perform many of the filtering tasks, along with software tools for psychometric testing.

\section{On boarding:}

"On boarding" is a term which describes the process of helping new employees become productive members of an organization. A well-planned introduction helps new employees become fully operational quickly and is often integrated with a new company and environment. On boarding is included in the recruitment process for retention purposes. Many companies have on boarding campaigns in hopes to retain top talent that is new to the company; campaigns may last anywhere from 1 week to 6 months.

\subsection{Selection}

Selection can be conceptualized in terms of either choosing the fit candidates, or rejecting the unfit candidates, or a combination of both. So, selection process assumes rightly that, there is more number of candidates actually selected, where the candidates are made available through recruitment process. Therefore, in simple terms, selection is a process in employment function which starts immediately upon of resumes and application letters, the major concern being reviewing resumes for basic qualification.

"Selection is the process of differentiating between applicants in order to identify those with a greater likelihood of success in a job".

\section{Selection procedure}

Selection is a long process, commencing from the elementary interview of the applicants and ending with the contract of employment. There is no standard selection procedure to be used in all organizations or for all jobs. The complexity of selection procedure increases with the level and responsibility of the position to be filled. The strategy and method used for selecting employees varies from organization to organization and from one job to another.

Selection decisions should be made after using a range of tools appropriate to the time and resources available. The most common techniques are described below. Care should be taken to use techniques which are relevant to the job and the business reviewed to ensure their fairness and reliability.

\section{Steps in selection process}

1. Study and know about employment laws that affect that after the selecting process.

2. Prepare a current position description for the vacant position or verify that the existing position description is current.

3. Prepare and issue a vacancy announcement

4. Prepare application screening criteria.

5. Prepare questions and screening criteria for the selection interview.

6. Select the top-ranking individuals for interviewing

7. Conduct interviews based on established criteria.

8. Reference checking information

9. Orientation

10. Probationary period

Steps in scientific selecting process:

Receiving applications, Screening of applications, Employment tests, Rejection of unsuitable candidates, Interview, Reference checking, Medical examination, Final selection, Selection tests

\section{Objective of the Study}

$>$ To know the perception of the employee about the recruitment and selection procedure.

To study the various methods of recruitment and selection process in Wipro Infrastructure Engineering at Hindupur.

$>$ To assess the attitude of the employee towards the recruitment and selection procedure.

To find out whether the management fulfill the commitment during the interviews. 


\section{Scope for the Study}

The present study aims at analyzing the recruitment, selection, placement, and induction policy in Wipro Infrastructure Engineering, Hindupur. The study has a wide scope in generating good awareness levels, regarding recruitment, selection, placement and induction policy in both management and employees which helps a lot in planning and implementing the right and suitable policy in organization. The explore the views expressed by the respondents about the adequacy of existing system there by examine critically and providing solution in an attempt to better the system.

\section{Research Methodology}

The design of research project specifies both the data that are needed and how they are to be obtained. The step in data collection process is to look for primary data as well as secondary data.

\section{Primary Data:}

Primary data are data that are collected to help solve a problem or take advantage of an opportunity on which a decision is pending. An important source of primary data is serving a research. The various types of surveys (personal, computer and telephone) the interviews that have been taken from the general manager, HR manager and some of the executives have helped a lot in collecting the information.

\section{Secondary Data:}

Secondary data are that were developed for some purpose other than helping to solve the problems at hand. The secondary data those are available to relatively quick and inspective to obtain. Internal sources can be classified in to for broad categories: Appraisal reports, training reports, miscellaneous records and internal expo.

\section{Data Analysis and Interpretatio 5.1 The openings in the organization}

Table 1

\begin{tabular}{|c|c|c|c|c|c|c|}
\hline & FRIENDS & $\begin{array}{c}\text { JOB } \\
\text { PORTAL }\end{array}$ & $\begin{array}{l}\text { NEWS } \\
\text { PAPERS }\end{array}$ & OTHERS & $\begin{array}{l}\text { NO OF } \\
\text { RESPONDENTS }\end{array}$ & $\begin{array}{c}\% \text { OF } \\
\text { RESPONDENTS }\end{array}$ \\
\hline MANAGERS & $16.66 \%$ & 00 & ne 0 & $3.34 \%$ & ITIC $6=$ & 20 \\
\hline EXPERIENCED & $50.625 \%$ & $3.375 \%$ & 0 & 0 & 16 & 54 \\
\hline FRESHER ' $\mathrm{S}$ & $22.75 \%$ & $3.25 \%$ & 0 & 0 & 8 & 26 \\
\hline TOTAL & $90.035 \%$ & $6.625 \%$ & 0 & $3.34 \%$ & 30 & 100 \\
\hline
\end{tabular}

\section{Graph 1}

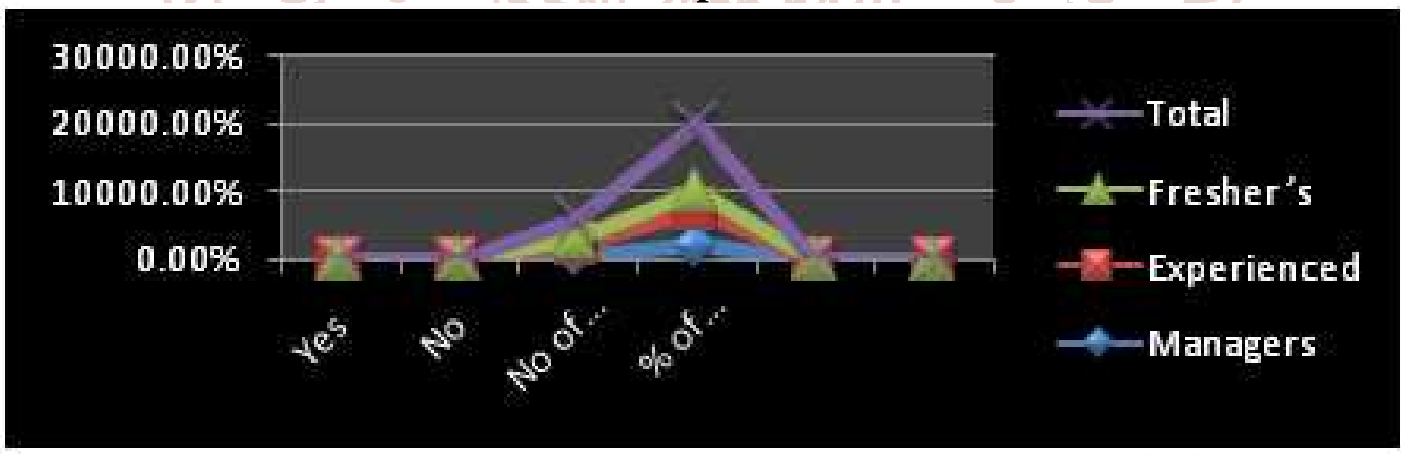

Interpretation: $90.035 \%$ of respondents came to know about the openings in the organization through friends. 6.625\% of respondents through Job portals and 3.34\% through other means (Direct Call from CEO).

\subsection{The major factor that made you to apply for this Organization}

\section{Table 2}

\begin{tabular}{|c|c|c|c|c|c|c|}
\hline & $\begin{array}{c}\text { Image of the } \\
\text { Organization }\end{array}$ & $\begin{array}{c}\text { Organization } \\
\text { Culture }\end{array}$ & Salary & $\begin{array}{c}\text { Job } \\
\text { Role }\end{array}$ & $\begin{array}{c}\text { No of } \\
\text { respondents }\end{array}$ & $\begin{array}{c}\text { \% of } \\
\text { respondents }\end{array}$ \\
\hline Managers & $03 \%$ & $0 \%$ & $3.75 \%$ & $16.62 \%$ & 6 & 20 \\
\hline Experienced & $10.5 \%$ & $0 \%$ & $6.65 \%$ & $30.37 \%$ & 16 & 54 \\
\hline Fresher's & $6.5 \%$ & $3.25 \%$ & $03.16 \%$ & $16.2 \%$ & 8 & 26 \\
\hline Total & $20 \%$ & $3.25 \%$ & $13.56 \%$ & $63.19 \%$ & 30 & 100 \\
\hline
\end{tabular}




\section{Graph 2}

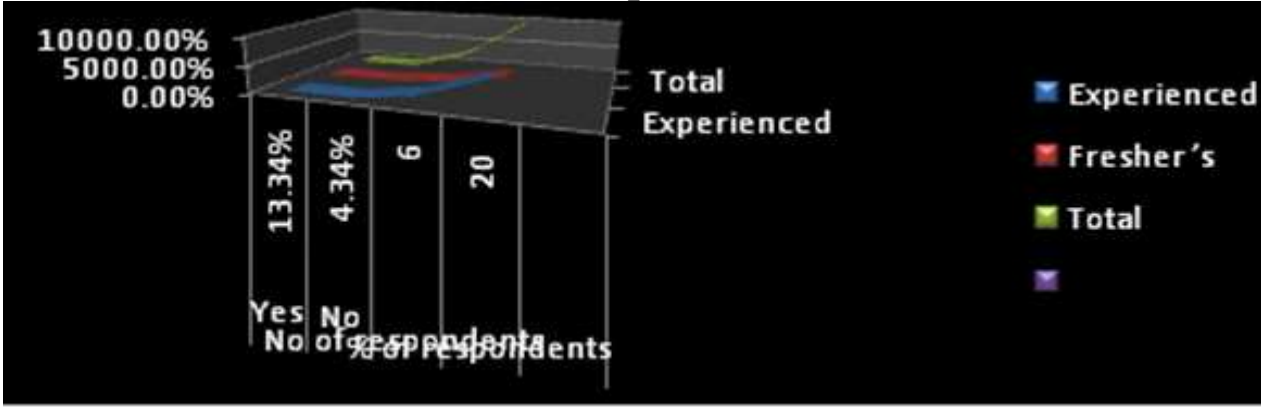

Interpretation: $20 \%$ of respondents are influenced by the Image of organization, $3.25 \%$ are influenced by Organization culture, $13.56 \%$ by Salary and $63.19 \%$ by Job Role.

\subsection{Happy with the Recruitment process}

Table 3

\begin{tabular}{|c|c|c|c|c|}
\hline & Yes & No & No of respondents & $\%$ of respondents \\
\hline Managers & $10 \%$ & $6 \%$ & 6 & 20 \\
\hline Experienced & $50 \%$ & $10 \%$ & 16 & 54 \\
\hline Fresher's & $20 \%$ & $4 \%$ & 8 & 26 \\
\hline Total & $80 \%$ & $20 \%$ & 30 & 100 \\
\hline
\end{tabular}

\section{Graph 3}

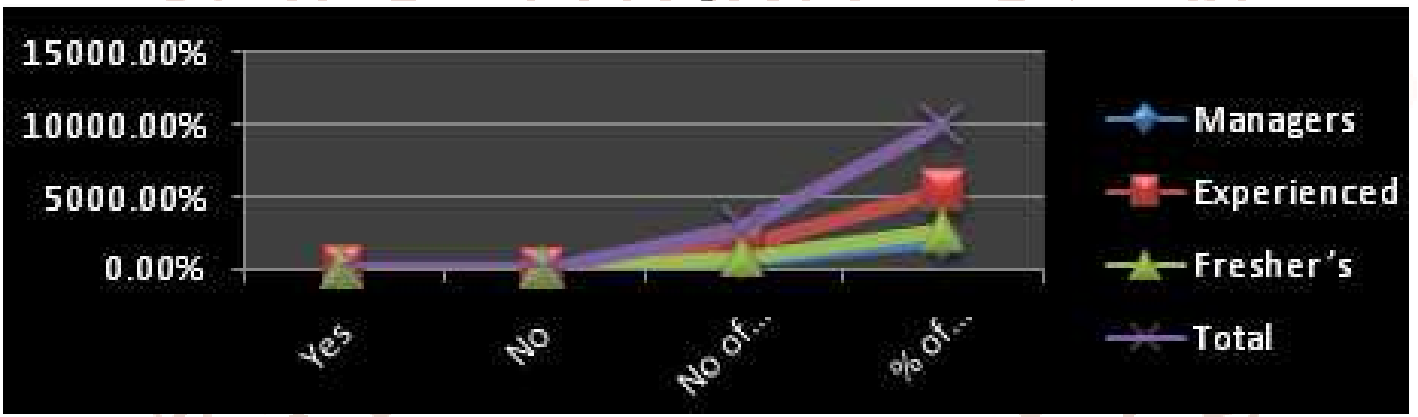

Interpretation: $80 \%$ of respondents are happy with recruitment process as well as $20 \%$ of respondents are not satisfied with recruitment process.

\subsection{Your first interaction with the company}

Table 4

\begin{tabular}{|c|c|c|c|c|c|c|}
\hline & Very Impressive & Good & Better & Bad & No of respondents & \% of respondents \\
\hline Managers & $2 \%$ & $20 \%$ & $2 \%$ & 0 & 6 & 20 \\
\hline Experienced & $6.12 \%$ & $33.76 \%$ & $6.12 \%$ & 0 & 16 & 54 \\
\hline Fresher's & $2 \%$ & $26 \%$ & $2 \%$ & 0 & 8 & 26 \\
\hline Total & $10.12 \%$ & $79.76 \%$ & $10.12 \%$ & 0 & 30 & 100 \\
\hline
\end{tabular}

\section{Graph 4}

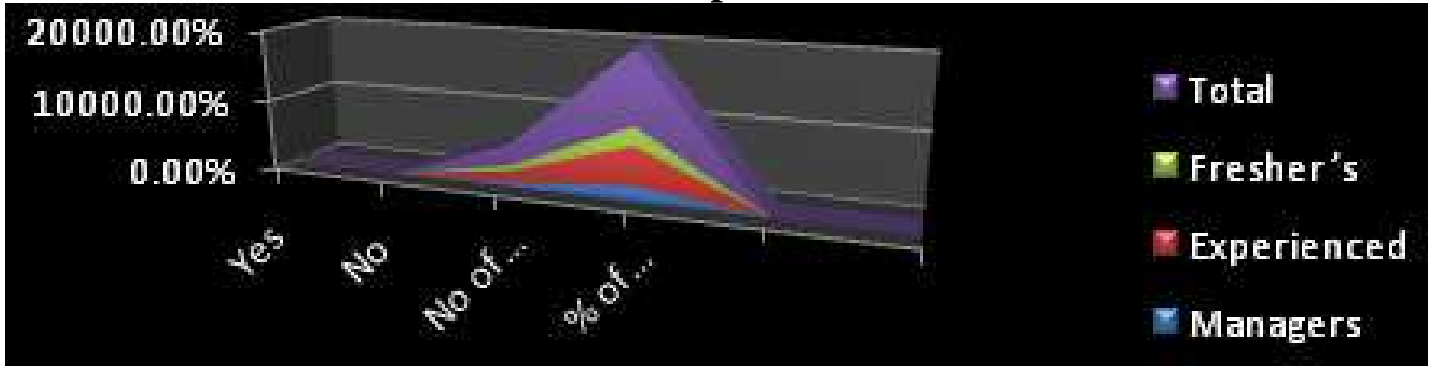

Interpretation: $10.12 \%$ of respondents felt Very impressive when they interacted for the first time with the company, $79.76 \%$ feel good and $10.12 \%$ of experienced employees felt better. 
International Journal of Trend in Scientific Research and Development (IJTSRD) ISSN: 2456-6470

5.5. Your feel about the interview panel

Table 5

\begin{tabular}{|c|c|c|c|c|c|c|}
\hline & Excellent & Good & Satisfactory & Poor & No of respondents & $\%$ of respondents \\
\hline Managers & $3 \%$ & $6.66 \%$ & $13.04 \%$ & 0 & 6 & 20 \\
\hline Experienced & $5.75 \%$ & $47.25 \%$ & $1.05 \%$ & 0 & 16 & 54 \\
\hline Fresher's & $4.5 \%$ & $9.75 \%$ & $9 \%$ & 0 & 8 & 26 \\
\hline Total & $13.25 \%$ & $63.66 \%$ & $23.09 \%$ & 0 & 30 & 100 \\
\hline
\end{tabular}

Graph 5

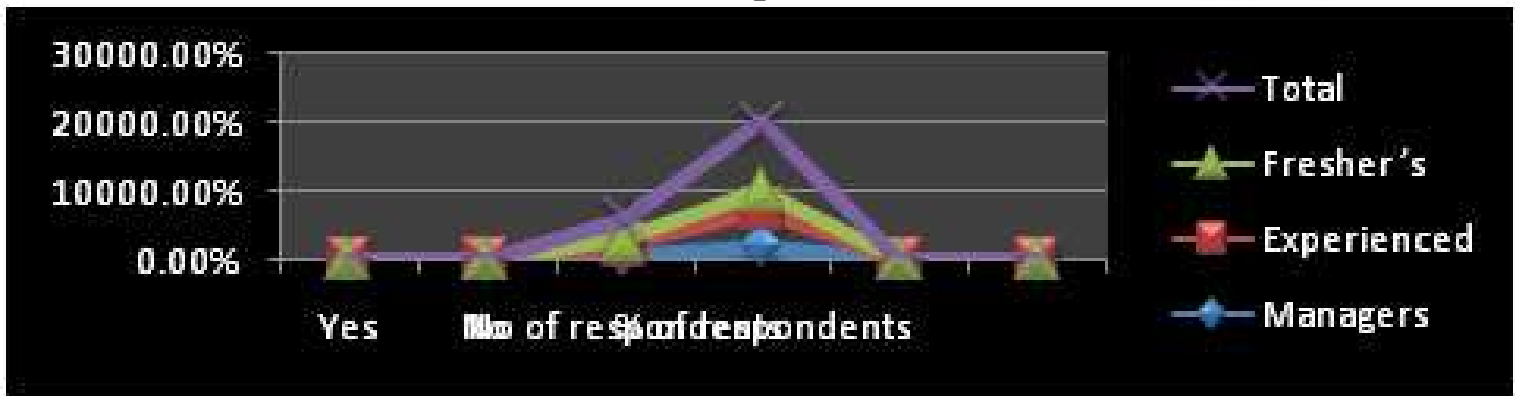

Interpretation: Only $13.25 \%$ of respondents feel Excellent about interview panel, $63.66 \%$ of employees feel good and $23.09 \%$

\subsection{The organization meets your expectations}

Table 6

\begin{tabular}{|c|c|c|c|c|}
\hline & Yes & No & No of respondents & \% of respondents \\
\hline Managers & $13.34 \%$ & $4.34 \%$ & 6 & 20 \\
\hline Experienced & $37.125 \%$ & $16.875 \%$ & 16 & 54 \\
\hline Fresher's & $22.75 \%$ & $5.57 \%$ & 8 & 26 \\
\hline Total & $73.215 \%$ & $26.785 \%$ & 30 & 100 \\
\hline
\end{tabular}

Graph 6

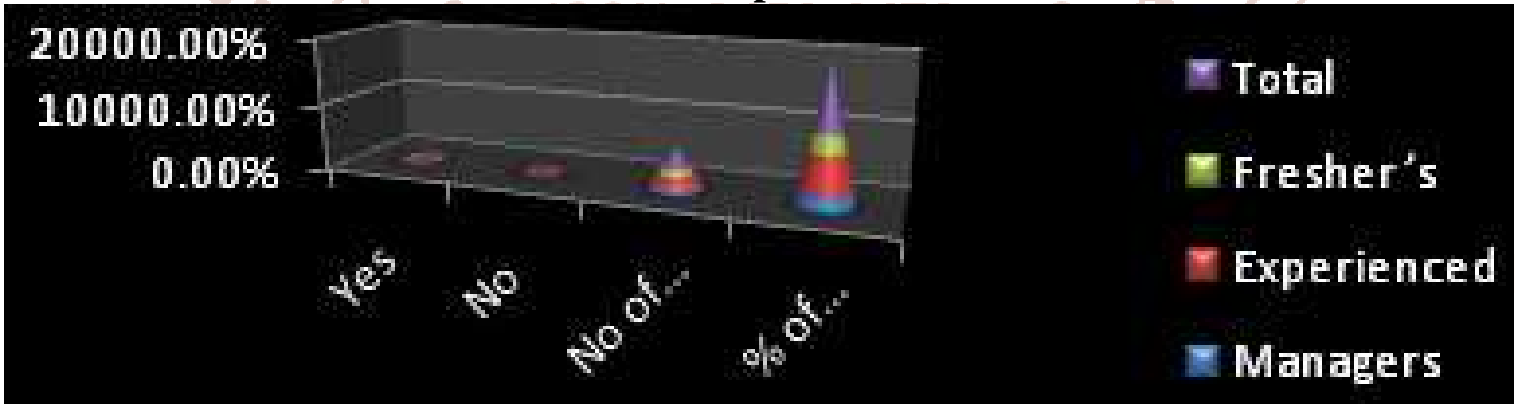

Interpretation: $04.34 \%$ of managers feel that the organization did not meet their expectations.73.215\% of respondents are happy with the Organization culture, Overall $26.785 \%$ of respondents are not happy.

5.7 Your thinking about Recruitment and selection procedure in this company

Table 7

\begin{tabular}{|c|c|c|c|c|c|c|}
\hline & $\begin{array}{c}\text { Highly } \\
\text { Satisfied }\end{array}$ & Satisfied & Dissatisfied & $\begin{array}{c}\text { Cannot } \\
\text { Say }\end{array}$ & $\begin{array}{c}\text { No of } \\
\text { respondents }\end{array}$ & $\begin{array}{c}\% \text { of } \\
\text { respondents }\end{array}$ \\
\hline Managers & $6 \%$ & $10 \%$ & $3.34 \%$ & $6.66 \%$ & 6 & 20 \\
\hline Experienced & $10.875 \%$ & $37.125 \%$ & 0 & 0 & 16 & 54 \\
\hline Fresher's & $3.25 \%$ & $19.5 \%$ & 0 & $3.25 \%$ & 8 & 26 \\
\hline Total & $20.125 \%$ & $66.625 \%$ & $3.34 \%$ & $9.91 \%$ & 30 & 100 \\
\hline
\end{tabular}




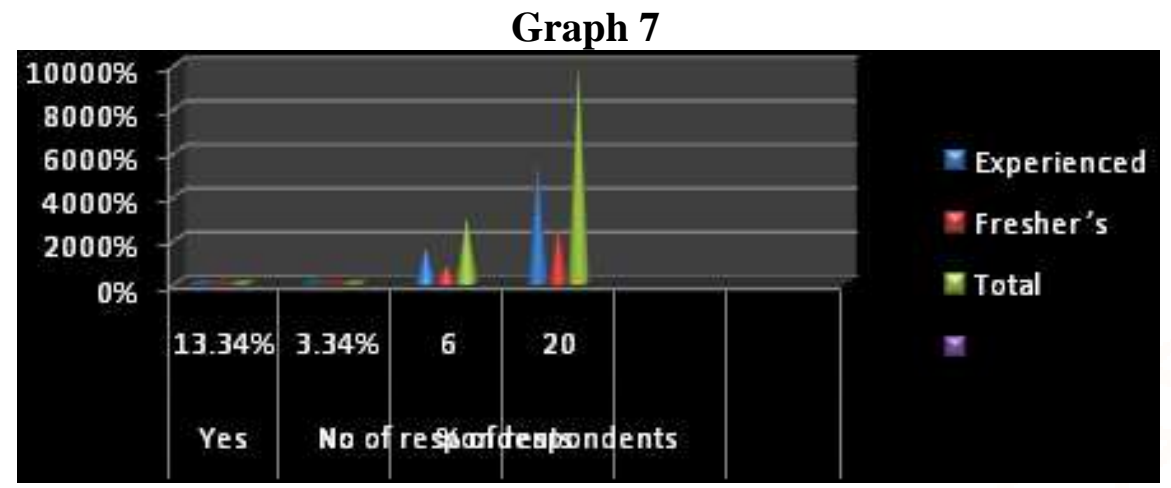

Interpretation: $6 \%$ of managers are highly satisfied, $10 \%$ are satisfied, 3.34\% of Managers are dissatisfied and $6.66 \%$ of managers have no opinion.

5.8 The organization management fulfills the commitment, which has given to you at the time of interview

Table 8

\begin{tabular}{|c|c|c|c|c|}
\hline & Yes & No & No of respondents & \% of respondents \\
\hline Managers & $13.34 \%$ & $2.34 \%$ & 6 & 20 \\
\hline Experienced & $50.625 \%$ & $5.57 \%$ & 16 & 54 \\
\hline Fresher's & $22.75 \%$ & $5.37 \%$ & 8 & 26 \\
\hline Total & $86.72 \%$ & $13.28 \%$ & 30 & 100 \\
\hline \multicolumn{5}{|c|}{} \\
\hline \multicolumn{5}{c|}{ Graph 8 } \\
\hline
\end{tabular}

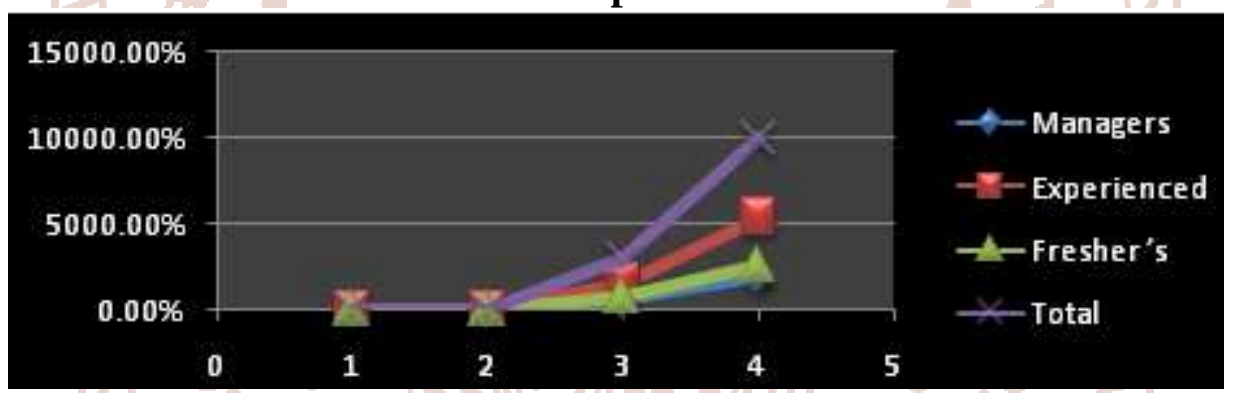

Interpretation: $2.34 \%$ managers, $5.57 \%$ of experienced and $5.37 \%$ of fresh employees think that the management has not fulfilled the commitment that has given to them at the time of interview; where as $86.72 \%$ of respondents feel that the organization has fulfilled.

\subsection{You feel that the organization follows definite recruitment procedure}

Table 9

\begin{tabular}{|c|c|c|c|c|c|c|}
\hline & Strongly & Agree & Disagree & Cannot say & No of respondents & $\%$ of respondents \\
\hline Managers & $3 \%$ & $10 \%$ & $10.34 \%$ & $6.66 \%$ & 6 & 20 \\
\hline Experienced & $5.75 \%$ & $27.12 \%$ & $3 \%$ & $10.13 \%$ & 16 & 54 \\
\hline Fresher's & $4.5 \%$ & $3.25 \%$ & $6.5 \%$ & $9.75 \%$ & 8 & 26 \\
\hline Total & $13.25 \%$ & $40.37 \%$ & $19.84 \%$ & $26.54 \%$ & 30 & 100 \\
\hline
\end{tabular}

\section{Graph 9}

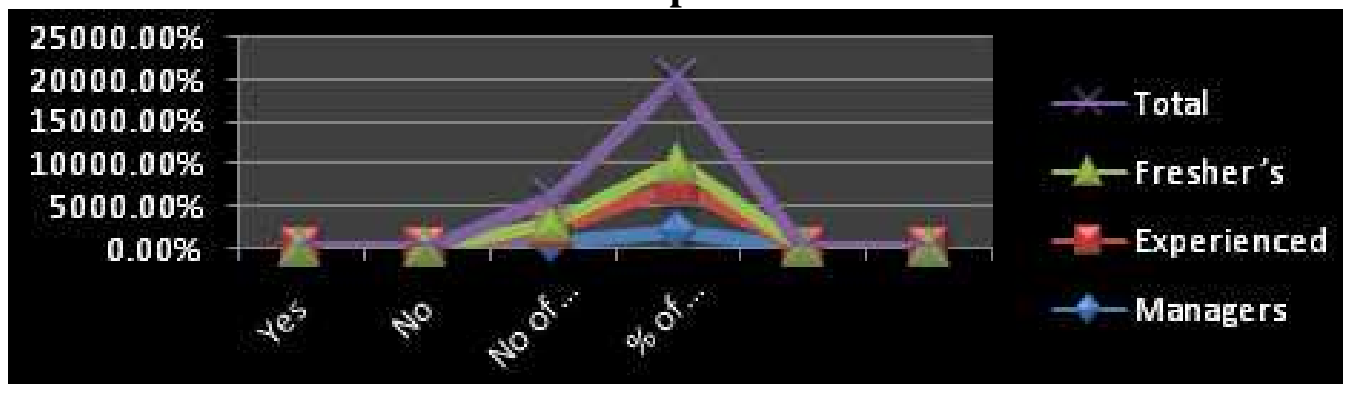


Interpretation: $3 \%$ managers strongly, $10 \%$ managers agreed, $10.34 \%$ of managers feel that the organization do not follow definite pattern of recruitment procedure and $6.66 \%$ of respondents have no opinion. In the overall organization $13.25 \%$ of respondents are strongly, $40.37 \%$ o respondents agreed, $19.84 \%$ of respondents managers feel that the organization do not follow definite pattern of recruitment procedure.

\subsection{Satisfied level with the salary offered}

Table 10

\begin{tabular}{|c|c|c|c|c|}
\hline & Yes & No & No of respondents & \% of respondents \\
\hline Managers & $13.34 \%$ & $3.34 \%$ & 6 & 20 \\
\hline Experienced & $54 \%$ & $7.32 \%$ & 16 & 54 \\
\hline Fresher's & $6.5 \%$ & $15.5 \%$ & 8 & 26 \\
\hline Total & $73.84 \%$ & $26.16 \%$ & 30 & 100 \\
\hline
\end{tabular}

Graph 10

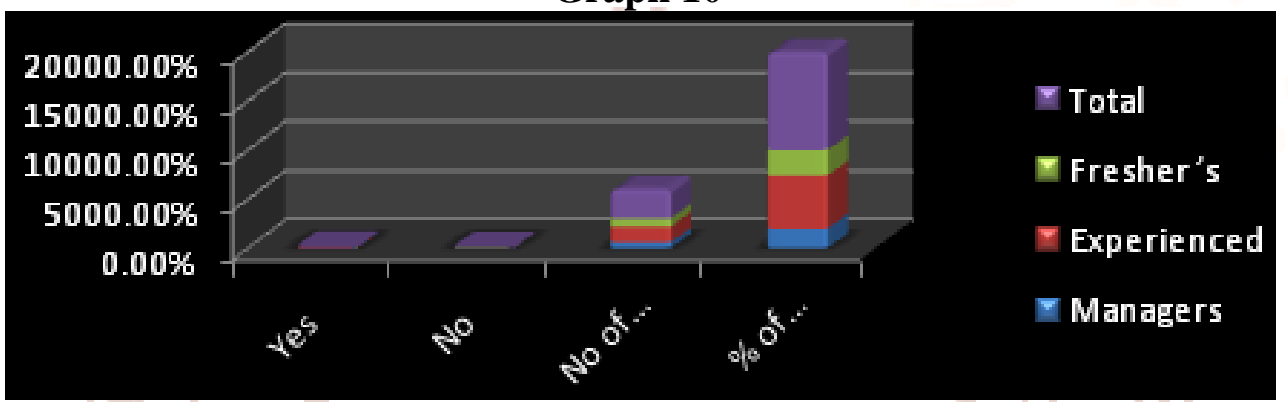

Interpretation: $73.84 \%$ of respondents are satisfied with salary offered, $26.16 \%$ of respondents are not satisfied salary offered by organization.

\section{Findings}

$>80 \%$ of Respondents are happy with recruitment process.

$>$ The recruiter will conduct technical test for selection of the candidates. It was also found that job portals are using as major source for recruiting the candidates.

$>20 \%$ of the respondents are influenced by the image of the organization $3.25 \%$ are influenced by the organization culture $13.56 \%$ by salary and $63.19 \%$ by job role.

$>$ Most of the people respond happy with organization culture $2.34 \%$ managers, $5.57 \%$ of experienced and $5.37 \%$ of fresh employees think that the management has not fulfilled the commitment that has given to them at the time of interview; where as $86.72 \%$ of respondents feel that the organization has fulfilled.

\section{Suggestions}

$>$ It is suggested that facilities like food, transportation and night shift allowances are to be provided for betterment of the company.

$>$ Perfect recruitment procedure is to be followed.

$>$ H.R. manager round shall be included in the interview panel.
To make new employees settle quickly and become productive, Induction process is to be followed.

H.R manager must involve in salary fixation.

Common aptitude test should be conducted for every interviewee irrespective of experience and designation.

$>$ Grievance cell and feedback system need to be implemented for growth of organization.

Company's website is to be updated; it is suggested to add the requirement chronology in career's tab.

\section{Conclusion}

Every organization has difficulty in finding good people, when it comes to the long term survival and prosperity of the firm. In simple terms, recruitment is the set of activities a firm uses to attract job candidates possessing the abilities and attitudes necessary for the enterprises to achieve its objectives. The selection procedure is concerned with securing relevant information about an applicant; this information is secured in a number of steps or stages. Recruitment and selection are getting very much importance these days in the organization. It is very critical thing to evaluate the human resources. It is a systematic procedure that involves many activities. 
The process includes the step like HR Planning attracting applicant and screening them. It is very important activity as it provides right people in right place at right time. It is not an easy task as organization's future is depends on this activity. If suitable employees are selected which are benefited to the organization it is at safe but if decision goes wrong it can be dangerous to the organization. So it is an activity for which HR Department gets very much importance. Recruitment and selection procedure and its policies changed as per the organization. And as for the Wipro Infrastructure Engineering Recruitment and Selection process strategy is linked with overall strategy of Quality and Continuous Improvement thus they try to build the best talent level of employees to up the level quality and market that they want to achieve. Its importance also gets changed as the organization changed according to the market need and recruiting and selecting process will be continues as the organization change.

\section{References:}

1. Achieving Excellence in Human Resources Management: An Assessment of Human Resource Functions Edward E. Lawler Iii; John W. Boudreau. Stanford Business Books, 2009

2. Anderson, N., Leivens, F., Van Dam, K., \& Ryam, A. M. (2004), Future perspectives on employee selection: Key directions for future research and practice. Applied Psychology: An International Review, 53, 487-501.

3. Appelbaum, S. H. (2001), Course Syllabus, Human Resource Management, Course designation number, AMBA624.Spring, Johan Molson Scholl of Business, Concordia University, Montreal.

4. Armstrong CP. Current Recruitment and Selection Practices: A National Survey of Fortune 1000 Firms. North American Journal of Psycology 2006; 489-496.
5. Aswathappa. K. Human Resource and Personal Management, 1997, TATA Me Graw hill Publishing Company Limited, New Delhi.

6. Cappelli P., Making the most of online Recruiting, Harvard Business Review 2001; 139-146

7. Duggan B. Should you outsource Recruitment. Emerald Management Review: Supply Management 2004; 26-27.

8. Essential of human resource management and industrial relations, subbarao Mumbai, Himalaya publishing house, 1996

9. French GR. Recruitment and Selection, Managing and Developing 2012; 12-32

10. Globalizing Human Resource Management Paul Sparrow; Chris Brewster; Hilary Harris. Rout ledge, 2004

11. Human Resource Champions: The Next Agenda for Adding Value and Delivering Results, Dave Ulrich, 1996

12. Human Resources Management: All the Information You Need to Manage Your Staff and Meet Your Business Objectives, Patricia Buhler (ebook) 2002

13. International Human Resource Management: A Multinational Company Perspective Monir $\mathrm{H}$. Tayeb. Oxford University Press, 2005

14. Strategic Human Resource Management: A Three-Stage Process Model and Its Influencing Factors Krishnan, Sandeep K.; Singh, Manjari. South Asian Journal of Management, Vol. 18, No. 1, January-March 2011

15. The Manager's Guide to HR: Hiring, Firing, Performance Evaluations, Documentation, Benefits, and Everything Else You Need to Know Max Muller. AMACOM, 2009 